\title{
$A L-\bar{A} L A M$ DALAM ALQURAN: \\ (Analisis tentang Ayat-ayat Penciptaan)
}

\author{
Muhammad Syarif Hasyim \\ PPs UIN Alauddin Makassar, Jl. Sultan Alauddin No. 63 Makassar \\ E-mail: mawomba@gmail.com
}

\begin{abstract}
Abstrak: Salah satu objek kajian filsafat adalah alam. Pemikiran tentang alam berproses terus kepada hal-hal yang di luar alam hingga sampai kepada satu kesimpulan bahwa keberadaan alam harus melalui proses. Para filosof berpendapat bahwa semua yang tercipta harus melalui proses, yaitu proses emanasi. Implikasi dari pendapat ini ialah alam itu qadim karena diciptakan oleh Allah sejak qidam dan azālī. Pendapat ini ditentang oleh para teolog (mutakallimin), mereka berpendapat bahwa alam ini baru, dan adanya dari yang tidak ada. Kedua pendapat yang berbeda ini dikuatkan dengan dalil-dalil Alquran. Interpretasi yang mereka lakukan terhadap ayat-ayat Alquran membuka peluang perbedaan pendapat tersebut, karena termterm yang digunakan dalam Alquran untuk menunjukkan makna penciptaan bervariasi, apalagi kalau merujuk kepada pendapat yang mengingkari adanya lafal-lafal al-tarāduf (sinonim) dalam Alquran. Oleh karena itu, kata khalaqa, bada'a dan fatara meskipun memiliki makna "menciptakan”, masing-masing kata ini memiliki subtansi makna tersendiri.
\end{abstract}

Abstract: One of the objects of the philosophy studies is the nature. The thought of the nature runs continually to the things beyond the nature (metaphysics) and eventually comes to a conclusion that the existence of the nature must be in process. The philosophers argued that all things created must be in process, namely the process of emanation. The implication of this argument is that the nature is qadim, because it was created by God since qidam and azālī. This argument was opposed by the theologists (mutakallimin). They said that the nature was something new and its existence was from nothing. These two different theories are supported by the dalīls of the Qur'an. Their interpretations on the verses of the Qur'an gave the opportunity to result in different argument. The reason is that the use of the 
terms in the Qur'an, which refer to the meaning of creating, is various, moreover when referring to the proposition which rejects the existence of the synonims in the Qur'an. Therefore, eventhough the meaning of the term "khalaqa, bada'a and fatara is "to create", each this single word has its own substancial meaning.

Kata Kunci: Alquran, filsafat, penciptaan alam, khalaqa, bada'a, fatara

\section{PENDAHULUAN}

Sifat manusia selalu ingin tahu apa yang ditangkap oleh indranya, minimal setelah indranya menangkap sesuatu, dia akan bertanya; apa itu? Dari mana asalnya? Bagaimana sehingga ada? Dan bagaimana kesudahannya? Pertanyaan-pertanyaan tersebut merupakan pertanyaan filosfis.

Demikian halnya dengan alam, pertanyaan yang terlintas; apa itu alam? ;bagaiamana sehingga ia ada?; dan bagaimana ujung dari alam ini? Pertanyaan tersebut telah berusaha untuk dijawab oleh para filosof, di antara mereka terjadi perbedaan tentang asalusul alam. Sehingga pertanyaan tidak sebatas tentang alam saja, tetapi pertanyaan-pertanyaan lain pun berdatangan sehingga sampai pada pertanyaan yang berhubungan dengan hakekat "wujud" atau "ada", dan ini merupakan objek filsafat.

Perdebatan atau pembicaraan terhadap apa yang telah dibicarakan sebelumnya oleh para filosof Yunani, telah melibatkan juga para filosof muslim. Para filosof muslim berusaha untuk menyesuaikan pendapat para filosof Yunani yang didasari oleh akal dengan agama yang bersumber dari wahyu. Dalam sejarah filsafat Islam dikenal bahwa al-Kindi merupakan filosof muslim pertama yang meretas jalan mengupayakan pemaduan atau keselarasan antara filsafat dan agama, akal dan wahyu. Menurut filosof muslim ini, antara keduanya tidak bertentangan,

${ }^{1}$ Zakarīya Basyīr Imām, Tārīkh al-Falsafah al-Islāmīyah, Dirāsah Madkhalīyah Muyassarah (Cet. ke-1; Khurtūm: Dār al-Sūdānīyah li al-Kutub, 1998), 84. 
karena keduanya adalah ilmu tentang kebenaran. ${ }^{2}$ Untuk memperkuat alasannaya, al-Kindi yang diikuti oleh filosof-filosof muslim setelahnya; al-Farabi dan Ibn Sina, telah menjadikan ayatayat Alquran sebagai landasan utamnaya, bahwa kerja filsafat merupakan anjuran Alquran. ${ }^{3}$ Di antara ayat-ayat Alquran yang selalu dijadikan landasan adalah: Q.S. al-A'rāf (7):185:

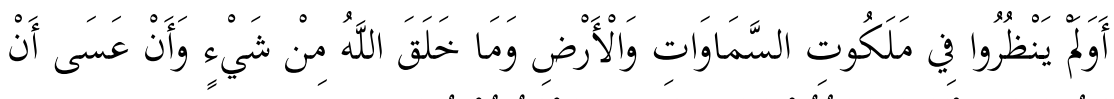

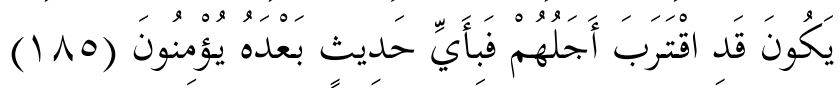

Dan apakah mereka tidak memperhatikan kerajaan langit dan bumi dan segala sesuatu yang diciptakan Allah, dan kemungkinan telah dekatnya waktu (kebinasaan) mereka? lalu berita manakah lagi setelah ini yang akan mereka percaya? ${ }^{4}$

\section{Q.S. al-Baqarah (2):164.}

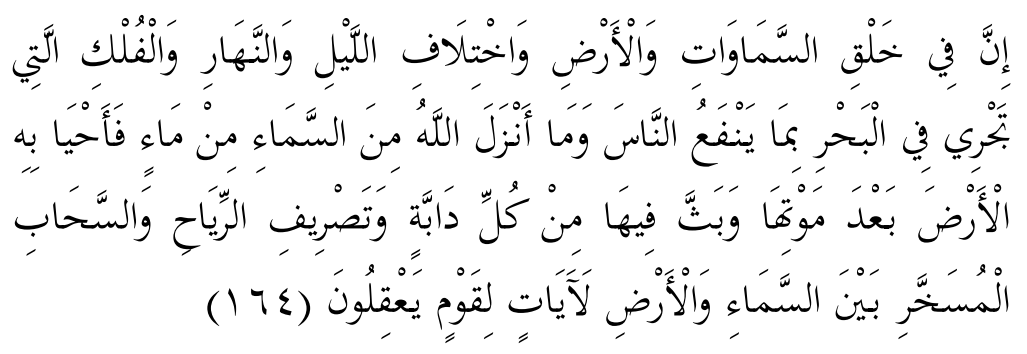

Sesungguhnya dalam penciptaan langit dan bumi, pergantian malam dan siang, kapal yang berlayar di laut dengan (muatan) yang bermanfaat bagi manusia, apa yang diturunkan Allah dari langit berupa air, lalu dengan itu dihidupkan-Nya bumi setelah mati (kering), dan Dia tebarkan di dalamnya bermacam-macam binatang, dan perkisaran angin dan awan yang dikendalikan antara langit dan bumi; (semua itu) sungguh, merupakan tanda-tanda (kebesaran Allah) bagi orang-orang yang mengerti. ${ }^{5}$

${ }^{2}$ Sirajuddin Zar, Filsafat Islam, Filosof dan Filsafatnya (Cet. ke-4; Jakarta: PT. Raja Grafindo Persada, 2010), h. 115.

${ }^{3}$ Zakarīya Basyīr Imām, Tārīkh al-Falsafah ..., h. 85.

${ }^{4}$ Departmen Agama, Mushaf Al-Qur'an Terjemah, edisi 2002 (Jakarta: Pena Pundi Aksara, 2006), h. 175

${ }^{5}$ Ibid. 
Berbicara tentang yang "ada" atau "hakekat al-wujūd atau al-maujūd? Tidak terlepas dari pembicaraan tentang alam, dia juga merupakan obyek bahasan filsafat, karena alam adalah realitas dari kekuasaan Allah, atau dengan bahasa Alquran merupakan ayat-ayat Allah swt. Para filosof, khususnya filosof muslim; mereka membangun konsep pemikiran mereka tentang alam berdasarkan ayat-ayat Alquran.

\section{BATASAN ALAM}

Kata ini, telah menjadi bahasa Indonesia, yang merupakan serapan dari bahasa Arab. Dalam bahasa Arab, kata ini berakar dari kata عang mempunyai arti dasar bekas atau tanda sesuatu yang membedakan dengan yang lain. ${ }^{6}$

Di dalam bahasa Indonesia, alam mempunyai bermacammacam arti, antara lain: 1). dunia; 2). segala yang ada di langit dan di bumi (seperti bumi, bintang-bintang,kekuatan-kekuatan); 3. daerah (keadaan, masa, kehidupan, dan sebagainya); 3). segala sesuatu yang termasuk dalam satu lingkungan (golongan dsb) dan dianggap sebagai satu keutuhan; 4. segala daya (kekuatan dsb.) yg menyebabkan terjadinya dan seakan-akan mengatur segala sesuatu yang ada di dunia ini, seperti: hukum alam; ilmu alam. ${ }^{7}$

Dari makna etimologi yang dikemukakan, dapat disimpulkan bahwa alam adalah semua yang ada; baik yang bersifat materi atau nonmateri, yang dilihat atau yang tidak. Tuhan tidak termasuk alam, walaupun Dia “Ada”, karena Dia tidak bersifat materi atau non materi.

Berangkat dari pengertian bahasa ini, para ulama memberikan definisi tidak jauh berbeda dengan makna bahasa tersebut. Al-Rāgib al-Asfahānīy (w. 502 H.), memberikan batasan

\footnotetext{
${ }^{6} \mathrm{Abū}$ al-Husein Ahmad ibn Fāris ibn Zakarīya, Mu'jam Maqāyīs al-Lugah (Cet. ke-1; Beirut: Dār Ihyā al-Turās al-'Arabīy, 2001), h. 663.

${ }^{7}$ Tim Redaksi Kamus Bahasa Indonesia, Kamus Bahasa Indonesia (Jakarta: Pusat Bahasa Departemen Pendidikan Nasional, 2008), h. 33-34.
} 
bahwa "al-ālam" adalah nama orbit dan apa yang dihimpunnya dari jauhar (subtansi) dan 'arad (accident), makna dasarnya adalah nama yang diperuntukkan kepada sesuatu yang dikenal. Al-'ālam adalah alat dalam memberikan petunjuk untuk mengetahui pembuatnya. ${ }^{8} \quad$ Makna yang hampir sama juga disampaikan oleh al-Jurjāni (740-816 H.) bahwa "ālam" "semua yang ada selain Allah. Karena semua yang ada merupakan bukti keberadaan-Nya. ${ }^{9}$

Dalam al-Mu'jam al-Falsafíy disebutkan bahwa alam mempunyai dua pengertian, yaitu: makna umum seperti yang telah disebutkan, dan makna khusus, yaitu segala seseuatu yang ada dalam satu kelompok yang sejenis. ${ }^{10}$ Selanjutnya makna alam juga dapat dibagi menjadi al-'âlam al-suflìy dan al-'âlam al-'ulwìy. Al-'ālam al-suflīy yaitu 'ālam al-Kaun (alam semesta) dan al-fasād (yang akan mengalami kerusakan), dan al-ālam al-'ulwìy, yaitu ālam al-aflāk dan apa yang ada di dalamnya, yang terdiri dari al'uqūl, al-nufūs dan al-ajrām."

Selain term ālam, yang menunjukkan makna alam, dalam bahasa Arab dikenal juga dengan term al-kaun. Hanya term ini tidak dijumpai dalam Alquran. Makna al-kaun dalam al-Mu'jam al-Falsafiy diartikan dengan wujudnya alam, yaitu alam yang mempunyai sistem yang teratur, atau dapat juga diartikan dengan yang tercipta dari tidak ada menjadi ada. Ilmu yang mempelajari tentang hukum umum tentang alam disebut ilm al-kaun. ${ }^{12}$ Dengan demikian, dapat dikatakan bahwa makna al-kaun lebih sempit dibanding dengan al-âlam.

${ }^{8} \mathrm{Abu}$ al-Qāsim al-Ḥusain ibn Muhammad al-Rāghib al-Asfahānī, alMufradāt fì Gharīb al-Qur'ān (Cet. ke-5; Beirut: Dār al-Ma'rifah, 2007), h. 348349

${ }^{9}$ Al-'Allāmah Ali ibn Muhammad al-Syarīf al-Jurjānī, Kitāb al-Ta'rīfăt (Beirut: Maktabah Lubnān, 1985), h. 149.

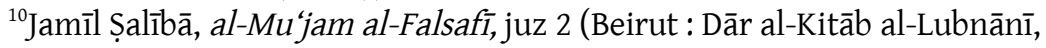
1982), h. 46.

${ }^{11}$ Ibid

${ }^{12}$ Ibid., h. 246. 
Dalam Alquran term al-'ālam tidak dijumpai dalam bentuk tunggal (mufrad), kecuali dalam bentuk plural "العالمين" (jama), bentuk ini disebutkan sebanyak 74 kali, dan dari 74 kali itu sebanyak 42 kali di-mudāf-kan kepada rabb. ${ }^{13}$ Hal ini menunjukkan bahwa adanya alam-alam lain selain alam kita, dan semua alam ini dibawah kendali-Nya. Al-Rāzi ketika menafsirkan Q.S. al-Fātihah (2):2.

Segala puji bagi Allah, Tuhan semesta alam

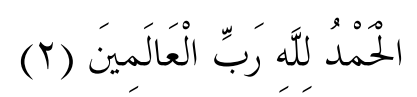

menyebutkan telah dibuktikan bahwa Allah mampu mengaktualkan segala kemungkinan, demikianlah Dia Yang Maha Tinggi mampu menciptakan jutaan alam di luar alam ini, masingmasing lebih besar dan massif daripada alam ini, dan argumen para filosof mengenai keunikan alam ini adalah lemah dan sangat tidak memadai karena didasarkan pada premis-premis yang tidak benar. $^{14}$

dijadikan jamak dengan penambahan yā dan nūn, karena manusia termasuk dalam pengertian al-ālam, manusia apabila bersama yang lain hukumnya yang diberlakukan. Namun ada juga yang berpendapat bahwa yang dimaksud dengan al'ālaminn dalam Alquran adalah malaikat, jin dan manusia. ${ }^{15}$

Penjelasan ayat-ayat Alquran tentang tentang alam raya disebut dengan ayat-ayat kauniyah dan banyak menggunakan kata atau lafal السماء (langit) atau السماوات (langit-langit) yang hampir selalu bergandengan dengan lafal الأرض (bumi). Kata السماء dalam bentuk tunggal disebutkan dalam Alquran sebanyak 120 kali, dan 190 kali dalam bentuk jamak, kata الأرض digunakan sebanyak 460 kali, ungkapan langit dan bumi atau langit-langit

${ }^{13}$ Muhammmad Fu'ād 'Abd al-Bāqī, al-Mu'jam al-Mufahras li al-Fāz alQur'ān al-Karīm (Cet. ke-3; Cairo: Dār al-Hadīs, 1991), h. 609-611.

${ }^{14}$ Al-Imām Muhammad al-Rāzīy Fakhr al-Dīn ibn al-'Allamah Diyā' alDīn, Tafsìr al-Fakhr al-Rāzīy al-Mushtahir bi Tafsīr al-Kabīr auw Mafātīh alGhaib, juz 1 (Cet. ke1; Beirut: Dār al-Fikr, 1981), h.14.

${ }^{15}$ Al-Asfahānīy, al-Mufradāt ... h. 349. 
dan bumi dikemukakan lebih dari 200 kali. $^{16}$ Kenyataan ini mengharuskan untuk dikatakan bahwa sangat sulit untuk membahas yang satu tanpa mengikutsertakan yang lain.

Dengan demikian, saat Allah swt. memberitakan proses terjadinya alam maka objeknya adalah langit dan bumi serta segala sesuatu yang ada di antara keduanya termasuk angkasa, karena menurut pengertian bahasa bahwa السماء mempunyai makna dasar "di atas" atau "tinggi". ${ }^{17}$ Alquran tidak menggunakan lafal dunyā, karena pasangan dunyāadalah akhirat. Hal ini bermakna bahwa langit dan bumi mewakili dimensi vertikal dan statis dari kosmos, sedangkan dunia dan akhirat mewakili hubungan horizontal dan dinamis antara situasi kita sekarang dalam kehidupan ini, dan situasi masa depan kita setelah kematian. Hubungan statis antara langit dan bumi akan tetap kuat hingga hari akhir, namun selanjutnya ia akan hidup dalam bentuk yang telah berubah. ${ }^{18}$ Sebagaimana dalam Q.S. Ibrāhīm (14):48.

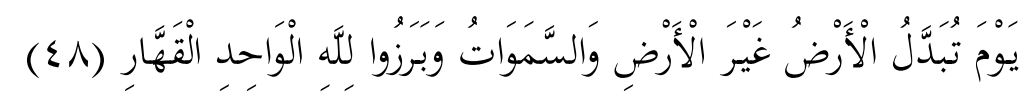

(yaitu) pada hari (ketika) bumi diganti dengan bumi yang lain dan (demikian pula) langit, dan meraka manusia berkumpul (di padang Mahsyar) menghadap Allah yang Maha Esa lagi Maha Perkasa. ${ }^{19}$

Dengan uraian di atas, maka yang dimaksud dengan alam dalam Alqurab adalah segala sesuatu selain Allah, namun apabila berbicara tentang penciptaan, maka yang dimaksud adalah langit dan bumi dan apa yang ada di antara keduanya.

${ }^{16}$ Muhammmad Fu'ad 'Abd al-Bāqī, al-Mu'jam al-Mufahras ..., h. 35-42 dan h. 459-465.

${ }^{17}$ Aḥmad ibn Fāris ibn Zakarīya, Mu'jam Maqāȳ̄s ..., h. 469.

${ }^{18}$ Sachiko Murata: The Tao of Islam, terj. Rahmani Astuti dan M.S. Nasrullah (Cet. ke-9; Bandung, PT. Mizan Pustaka, 2004), 169.

${ }^{19}$ Departemen Agama, Mushaf Al-Qur'an ..., h. 


\section{ASAL-USUL DAN PROSES TERJADINYA ALAM}

\section{Asal Usul Alam}

Salah satu yang menjadi perdebatan antara para filosof dan teolog muslim (Asy'arīyah), adalah tentang asal usul alam. Para teolog (mutakallimin) mengatakan bahwa alam ini baharu, dan adanya dari yang tidak ada. ${ }^{20}$ Pandangan teolog sejalan dengan al-Kindi yang berpendapat bahwa alam diciptakan dari ketiadaan, dia merupakan ciptaan Allah, beredar menurut aturannya (sunnatullah) tidak qadim tetapi mempunyai permulaan. ${ }^{21}$

Sementara filosof lain, dalam hal ini Ibn Sina dan diikuti oleh al-Farābi berpendapat bahwa alam qadīm karena diciptakan oleh Allah sejak qidam dan azali, proses penciptaannya lewat emanasi. Akan tetapi, tentu Ibn Sina membedakan antara qadìmnya Allah dan alam. Perbedaan yang mendasar terletak pada sebab membuat alam terwujud. Keberadaan alam tidak didahului oleh zaman, maka alam qadīm dari segi zaman (taqaddum zamānīy). Adapun dari segi esensi, sebagai hasil ciptaan Allah secara emanasi atau pancaran, alam ini baharu (hudūth zātīy), sementara Allah taqaddum zātìy, Ia sebab yang ada dan pencipta Alam. ${ }^{22}$ Sementara Ibn Rusyd berpendapat tentang keazalian materi, tetapi beliau mengkritik pendapat para filosof bahwa proses terjadinya alam lewat emanasi. Menurut Ibn Rusyd alam diciptakan dari sesuatu yang sudah ada, yaitu al-māddah, penciptaan ini terus menerus sejak azali. Untuk mendukung argumentasinya, Ibn Rusyd merujuk kepada Alquran. Ibn Rusyd mengatakan bahwa firman Allah dalam Q.S. Hūd (11):7.

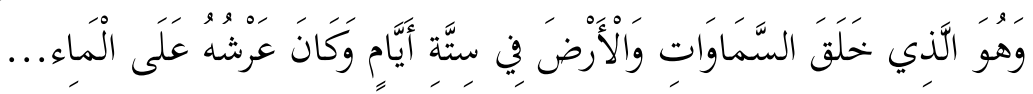

\footnotetext{
${ }^{20}$ Yahya Huwaidī, Dirāsāh fī 'Ilm al-Kalām wa al-Falsafat al-Islāmīyah (Cairo: Dār al-Ṡaqāfah, t.th.), h. 129. 52

${ }^{21}$ Zar, Filsafat Islam ...., h.53.

${ }^{22}$ Ibid., h. 103.
} 
dan Dia-lah yang menciptakan langit dan bumi dalam enam masa, dan adalah singgasana-Nya (sebelum itu) di atas air...

ayat ini zahirnya mengisyaratkan bahwa "ada" sebelum "yang ada" yaitu, al-'arsy dan air, ada waktu sebelum waktu ini, dan firman Allah dalam Q.S. Ibrāhīm/17:48.

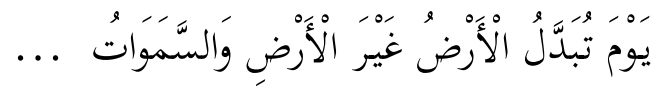

(yaitu) pada hari (ketika) bumi diganti dengan bumi yang lain dan (demikian pula) langit,...

Ayat ini pun mengisyartakan bahwa "ada yang kedua" setelah "yang ada ini", begitupun dengan firman Allah dalam Q.S. Fussilat (41):11.

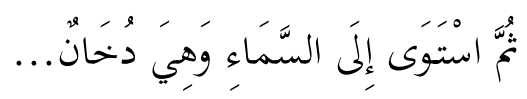

kemudian Dia menuju ke langit dan langit itu masih berupa asap,... yang mengisyaratkan bahwa langit diciptakan dari sesuatu. Walaupun Ibn Rusyd dikenal sebagai seorang yang rasional dan mempercayai apa yang dihasilkan oleh akal, namun dalam penetapan qidam-nya alam, beliau menganggap tidak termasuk yang dapat dianalogikan dan dibuktikan dengan penelitian, tetapi harus lewat pendengaran (wahyu). ${ }^{23}$

Kosmolog modern dalam menjelaskan penciptaan alam semesta berpegang pada teori Big Beng. Menurut teori ini, alam semesta teremas dalam singularis yang kemudian sekitar 15 miliar tahun meledak, pecah berkeping-keping dengan dahsyatnya. Pecahan inilah yang menjadi atom, bintang-bintang, dan galaksi-galaksi. Karena pemuaian alam semesta, galaksigalaksi bergerak saling menjauh dan akan terus bergerak. ${ }^{24}$

Hasil penelitian menunjukkan bahwa alam semesta tercipta dari ketiadaan. Menurut penjelasan A. Baiquni, seperti dikutip oleh Andi Rosadisastra, ketika terjadi ledakan yang sangat

${ }^{23}$ Muhammad al-Baișār, fi Falsafah ibn al-Rusyd, al-Wujūd wa al-Khulūd (Cet. ke-3; Beirut: Dār al-Kitāb al-Lubnānī, 1973), h. 67-68.

${ }^{24}$ Zar, Filsafat Islam ..., h.244. 
dahsyat bagaikan bola api, energi, materi, beserta ruang dan waktu keluar dengan kekuatan yang luar biasa dahsyat dengan temperatur dan kerapatan yang sangat tinggi. Dalam kondisi demikian molekul, atom, nucleus, proton, dan neutron tidak dapat muncul karena akan lebur terurai menjadi zarah-zarah sub nuklir. ${ }^{25}$

Dengan penjelasan ini, bahwa penelitian yang telah dilakukan oleh kosmolog, bahwa alam terjadi dari ketiadaan, seakan membantah pendapat Ibn Rusyd, dan mendukung pendapat teolog. Bagaimana dengan isyarat-isyarat Alquran.

Alquran seakan membenarkan kedua pendapat tersebut. Saat Ibn Rushd berpendapat bahwa alam diciptakan dari māddahseperti yang telah dijelaskan- beliau merujuk kepada Alquran (Q.S. Hūd (11): 117, Ibrāhīm (14 ):48, Fussilat 11), demikian juga para teolog, mereka berargumentasi dengan menggunakan خلق، بدع، : Alquran, bahwa Alquran menggunakan lafal-lafal seperti فظdan menurut al-Asfahāniy kesemuanya mengandung makna penciptaan dari yang tidak ada dan tidak ada contoh sebelumnya. ${ }^{26}$ Oleh karena itu, kata bid'ah (berasal dari kata bada'a) bermakna: berkata atau berbuat sesuatu yang tidak ada sebelumnya. ${ }^{27}$ Selain itu, Alquran juga menyebutkan bahwa penciptaan terjadi mempunyai permulaan, hal ini bermakna penciptaan mempunyai zaman atau waktu, berbeda dengan pendapt Ibn Rusyd yang berpendapat keberadaan alam tidak didahului oleh zaman.

Ibn Rusyd sangat beralasan dengan pendapatnya, karena di dalam Alquran tidak menginformasikan bagaimana asal usul alam secara keseluruhan, di dalam Alquran hanya menginformasikan tentang penciptaan langit dan bumi serta apa yang ada di antara

\footnotetext{
${ }^{25}$ Andi Rosadisastra, Metode Tafsir Ayat-ayat Sains dan Sosial (Cet. ke-1; Jakarta: Amzah, 2007), h. 197. 163,383

${ }^{26}$ Lihat masing-masing lafal tersebut, al-Asfahāni, al-Mufradāt ..., h. 49,

${ }^{27}$ Al-Rāzī, Tafsīr al-Fakhr ..., juz 4 h. 27.
} 
keduanya, bahkan penciptaan malaikat dari cahaya tidak diinformasikan secara jelas dalam Alquran. Perdebatan anatara teolog dan filosof, tidak akan pernah berahir, karena para teolog berangkat dari keyakinan bahwa semua selain Allah adalah alam, dan dia adalah makhluk, kalau makhluk pasti ada awalnya, yang sebelumnya tidak ada menjadi ada. sementara para filosof berpendapat bahwa keberadaan alam berasal dari māddah, dan adanya terus menerus sejak azali. Dengan demikian, penulis dapat katakan, bahwa al-māddah yang dimaksud oleh Ibn Rusyd tidak termasuk alam, sedangkan alam menurut teolog semua selain Allah, termasuk al-māddah.

Allah swt. tidak pernah menyuruh untuk memikirkan sesuatu di luar kemampuan manusia, termasuk apa yang diperdebatkan oleh para filosof. Adapun anjuran untuk memikirkan dan menyelidiki tentang makhluknya, -yang dimaksud adalah makhluk yang dapat dijangkau oleh akalolehnya itu, Alquran meyarankan untuk menyelediki bagaimana Tuhan mengawali penciptaan-Nya, Q.S. al-'Ankabūt (29):19-20.

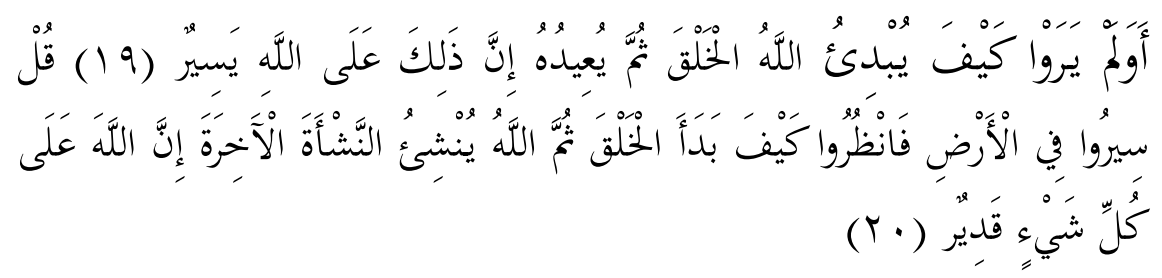

Dan Apakah mereka tidak memperhatikan bagaimana Allah menciptakan memulai penciptaan (makhluk), kemudian Dia mengulanginya (kembali). sungguh yang demikian itu mudah bagi Allah. Katakanlah: "Berjalanlah di bumi, Maka perhatikanlah bagaimana Allah memulai penciptaan (makhluk), kemudian Allah menjadikan kejadian yang akhir Sungguh, Allah Mahakuasa atas segala sesuatu. ${ }^{28}$

\section{Makna Penciptaan Alam}

Alquran tidak merinci bagaimana proses penciptaan, tetapi, dengan menelusuri term-term yang digunakan, para ulama dan

${ }^{28}$ Departemen Agama, Mushaf Al-Qur'an ..., h. 399. 
ilmuan berusaha untuk menyelaraskan hasil temuan mereka dengan informasi Alquran dengan cara menggali makna yang terkandung di balik term-term tersebut.

Seperti yang telah disebutkan, term atau kata yang خلق، بدع، : digunakan dan menujnjuk makna penciptaan antara lain فطر Penciptaan langit dan bumi dan apa yang ada di anatra keduanya, Alquran menyebutnya dalam waktu enam hari, itupun hanya digandengkan dengan lafal خلق seperti dalam Q.S. alFurqān (25):59.

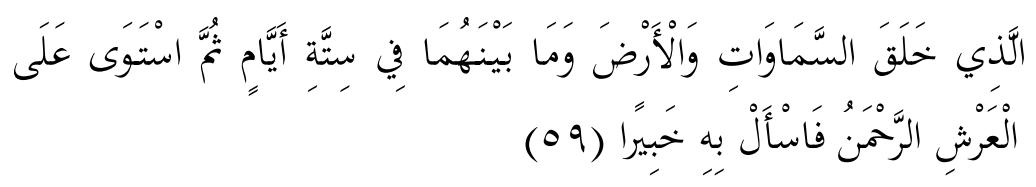

Yang menciptakan langit dan bumi dan apa yang ada antara keduanya dalam enam masa, kemudian Dia bersemayam di atas Arsy, (Dialah) yang Maha Pengasih, Maka Tanyakanlah (tentang Allah) kepada yang lebih mengetahui (Muhammad).

Informasi Alquran tentang waktu penciptaan dengan enam $^{29}$ hari terulang dalam Alquran sebanyak 7 kali; enam kali dengan memakai خَلقَ خَلَّنا di surah Qāf (50): $38 .^{30}$ Sedangkan penggunaan lafal yang semakna dengan "khalaqa" yaitu bada'a dan fatara tidak digandengkan dengan waktu, bahkan lafal bada'a hanya tiga kali penyebutannya, dua kali yanng disandarkan (di-dāfah-kan) kepada السَّمَاوَاتِ dengan menggunakan lafal "بديع" (badī) dan sekali dengan lafal "بدعا" (bid'an), 'yang bermakna pertama, tidak ada yang mendahului. Adapun "فطر" yang bermakna menciptakan langit dan bumi, disebutkan sebanyak delapan kali;

\footnotetext{
${ }^{29}$ Penyebutan angka enam dalam penciptaan langit dan bumi memerlukan penelitian lebih lanjut karena angka ini juga yang bergandengan dengan " فاطر السماوات والأرض dan " كن فيكون " dalam hal penciptaan secara umum.

${ }^{30}$ Muhammad Fu'ād 'Abd al-Bāqī, al-Mu'jam al-Mufahras ..., h. 439.

${ }^{31}$ Ibid., h. 147.
} 
dua kali dengan kata kerja "فطر" dan enam kali dengan isim fa 'il "فاطر."

Makna-makna dari ketiga kata ini dan penggunaannya dalam Alquran memang menimbulkan multi interpretasi, karena kata-kata tersebut dalam perspektif bahasa sangat memungkinkan untuk dikembangkan maknanya. Dan dengan melalui interpretasi-interpretasi dari ulama atau ilmuan dapat mengungkap rahasia-rahasia di balik lafal-lafal yang dijadikan simbol dalam mengungkapkan suatu term atau konsep-konsep dalam Alquran, yang kemudian dilanjutkan dengan penelitian seandainya makna tersebut membutuhkan observasi.

a. الخلق atau

Di dalam "Mu 'jam Maqāyīs al-Lugah" disebutkan bahwa kata yang terdiri dari huruf kha, lām, dan qāf mempunyai dua makna dasar, yaitu. penetapan sesuatu (تقدير الشيئ) dan kehalusan sesuatu (ملاسة الشيئ). Al-Asfahāni menjelaskan makna ini, bahwa dasar kata ini bermakna penetapan yang lurus atau seimbang (التقدير المستقيم)dan digunakan dalam mengadakan dari yang tidak ada (dasrnya) dan tidak ada contoh sebelumnya, seperti firman Allah: خحلَق السَّمَاوَات وَالَأَرْْ ( kata ini digunakan زلقكم : juga untuk penciptaan dari yańg ada, seperti firman-Nya: (Dialah yang menciptakan kamu dari satu jenis). ${ }^{34}$

Penggunaan kata خَخلَ da dalam penciptaan langit dan bumi dapat mengandung makna bahwa penciptaan berdasarkan suatu sistem yang Allah telah tetapkan, yaitu sistem yang sangat rapi. Makna ini difahami dari التقدير المستقيم penetapan yang lurus, teratur, dan tanpa celah, sehingga nampak sangat indah. Dengan demikian ada kesesuaian antara dua makna dasar dari kata ini.

\footnotetext{
${ }^{32}$ Ibid., h. 663-664.

${ }^{33}$ Aḥmad ibn Fāris ibn Zakarīya, Mu’jam Maqāyīs ..., h. 311.

${ }^{34}$ Al-Asfahānī, al-Mufradāt ..., h. 163.
} 
Selain makna tersebut, penggunaannya pada makna penciptaan langit dan bumi bisa memberikan tafsiran bahwa langit dan bumi serta angkasa lainnya tercipta melalui suatu proses yang mempunyai awal dan berasal dari sesuatu. Karena dari segi bahasa, خلق tidak secara jelas menunjukkan makna penciptaan dari yang tidak ada. Makna yang dikemukakan oleh alAsfahānīy bahwa خلقِ mengadakan dari yang tidak ada (asalnya) dan tidak ada contoh sebelumnya, salah satu penafsiran yang berlandaskan pada firman Allah yang lain, yaitu: بديع السماوات والارض

b. بديع

Kata ini mempunyai makna dasar memulai sesuatu dan membuatnya tidak berdasarkan contoh, ${ }^{35}$ al-Asfahāni menyebutkan, bila kata ini disandarkan kepada Allah swt swt. maka berarti Dia yang menjadikan sesuatu tanpa alat, tanpa māddah, tanpa waktu, dan tanpa tempat, ${ }^{36}$ seperti firman-Nya dalam Q.S. al-Baqarah (2):117.

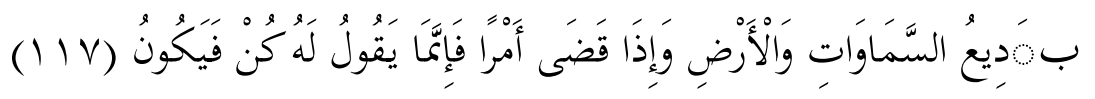

Allah Pencipta langit dan bumi, apabila Dia hendak menciptakan sesuatu, Dia hanya berkata kepadanya: "Jadilah!" maka jadilah sesuatu itu. $^{37}$

Ayat ini menjadi dasar bantahan terhadap yang mengatakan bahwa alam ini tercipta dari yang ada. ${ }^{38}$ Oleh karena itu, dalam Alquran, kata ini digandengkan dengan penciptaan langit dan bumi dengan menggunakan timbangan (wazan) faîl (șifah mushabbahah), dan menurut al-Allusi, lebih menegaskan, bahwa

${ }^{35}$ Ahmad ibn Fāris ibn Zakarīya, Mu'jam Maqāȳ̄s ..., h. 101

${ }^{36}$ Al-Asfahānī, al-Mufradāt ..., h. 49.

${ }^{37}$ Departemen Agama, Mushaf Al-Qur'an ..., h. 19.

${ }^{38}$ Abū al-Faḍl Syihāb al-Dīn al-Sayyid Maḥmūd al-Allūsī, Rūh al-Ma'ānī fi Tafsìr al-Qur'ān ai-'Azīm wa al-Sab' al-Masānìy (Beirut: Dār Ihyā' al-Turās al'Arabī, t.th.), h. 364. 
hanya Allah-lah Yang Mahapencipta atas segala sesuatu ${ }^{39}$ tanpa memerlukan alat, māddah, waktu, dan tempat. Dan pendapat tersebut dikuatkan lagi dengan penggalan berikutnya:

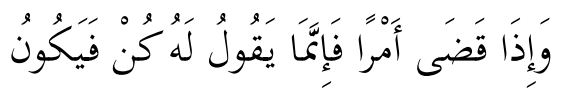

Kata بديع dapat bermakna sesuatu yang menakjubkan, mengembirakan, dan keanehan yang mengundang perhatian, karena penciptaan alam yang demikian, sehingga mengundang ketakjuban bagi Siapa saja yang memperhatikan dan memikirkannya, ${ }^{40}$ maka dalam ilmu balägah, bagian yang membahas tentang keindahan ini disebut dengan ilmu badī ${ }^{41}$

c. فطر

Adapun kata ini, arti dasarnya membuka sesuatu dan menampakkannya, seperti الفطر من الصوم (berbuka dari puasa). Dihubungkannya lafal ini dengan penciptaan, dapat diartikan memulai sesuatu pekerjaan, dalam hal ini menciptakannya. Al"فاطر : مبتدعهما ومبتدئهما وخالقهما mempunyai makna السماوات والأرض" ، (mengadakan, memulai, dan menciptakan), kemudian beliau menguatkan pengertian ini dengan riwayat:

$$
\text { حن إثنا به ابن وكيع قال، حدثنا يهيى بن سعيد القطان، عن سفيان، }
$$

${ }^{39} \mathrm{Ibid}$.

${ }^{40}$ Ibn Abū al-Ișba' al-Mișrī, Badīì al-Qur'ān, tahqū̃ Hifnīy Muhammad Sharaf (Cairo: Nahdat al-Misr, t.th.), h. 9.

${ }^{41}$ Al-Sayyid Aḥmad al-Hāshimī, Jawāhir al-Balāghah fī al-Ma'ānī wa alBayān wa al-Badī' (Cet. ke-1; Beirūt: Maktabah al'Așrīyah, 1999), h. 298.

${ }^{42}$ Ahmmad ibn Fāris ibn Zakarīya, Mu'jam Maqāyīs ..., h. 820. 


$$
\begin{aligned}
& \text { لا أدري ما"فاطر السماوات والأرض"، حتى أتاني أعرابيّان يختصمان في }
\end{aligned}
$$

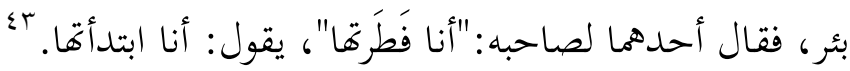

(Telah Berbicara kepada kami Ibn Wakī‘, berkata: telah berbicara kepada kami Yahya ibn Sa'īd al-Qațțān, dari Sufyān, dari Ibrāhīm ibn Muhājir, dari Mujāhid berkata: saya telah mendengar dari Ibn Abbas berkata: sebelumnya saya tidak mengetahui apa makna: "فاطر السماوات والأرض sampai datang kepada saya dua orang A'rābīy yang bertengkar tentang sebuah

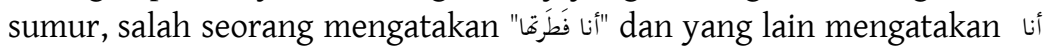
(ابتدأقها

Lafal ini, menurut penulis bisa bermakna, bentuk penciptaan dengan penetapan hukum, sifat atau karakter yang akan berlaku pada setiap alam. Karena dengan hal-hal tersebut, sesuai dengan makna bahasa, setiap alam akan lebih jelas identitasnya dan nampak bagi siapa saja yang meneliti penciptaan tersebut.

Dari ketiga kata yang menunjukkan makna penciptaan dalam Alquran, penulis menyimpulkan bahwa lafal-lafal tersebut merupakan tingkatan penciptaan alam. Pertama, dengan menggunakan lafal بديع secara umum bermakna tentang penciptaan, di tingkat ini, Allah menciptakan -sebagaimana telah dijelaskan- tanpa pengantara, tanpa keikutsertaan yang lain, bahkan dapat dikatakan tanpa proses. Oleh karena itu, penggunaannya dalam Alquran tidak dengan kata kerja, dan hanya diperuntukkan untuk penciptaan, langit dan bumi; kedua, penciptaan dengan penggunaan kata خحلق penciptaan bisa melalui proses, bisa berasal dari sesuatu yang sudah ada, tetapi bisa juga bermakna seperti بديع, olehnya itu, penggunaannya dalam Alquran, dijumpai dengan memakai damīr (kata ganti) yang menunjukkan orang pertama jama' (kami)

${ }^{43} \mathrm{Abū}$ Ja'far Muhammad ibn Jarīr al-Tabarī, Tafsīr al-Tabarī, Jāmi ${ }^{\star}$ alBayān 'an Ta'wīl Āy al-Qur'ān, tahqīi Abdullah ibn Abd al-Muhsin al-Turkī, juz 9 (Cet. ke-1; Cairo: Dār Hejr, 2001), h. 175. 
"حَلَقَنَا" , hal ini menunjukkan bahwa ada penciptaan melalui proses dan keikutsertaan yang lain; dan ketiga, dengan menggunakan kata فطر, dapat bermakna penciptaan karakter atau sifat dan hukum dasar yang akan berlaku pada setiap alam. Dengan dasar pemaknaan seperti ini, maka para ulama saat menafsirkan Q.S. al-Rūm (30):30.

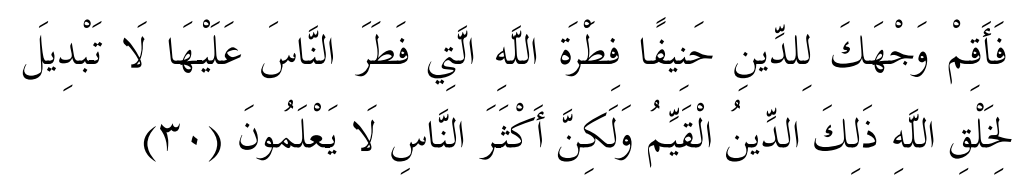

Maka hadapkanlah wajahmu dengan Lurus kepada agama (Islam); (sesuai) fitrah Allahdisebab Dia telah menciptakan manusia menurut (fitrah) itu. tidak ada peubahan pada ciptaan Allah. (Itulah) agama yang lurus; tetapi kebanyakan manusia tidak mengetahui. ${ }^{44}$

Ayat tersebut ditafsirkan seperti yang tercantum dalam catatan kaki (footnote) terjamah Departemen Agama bahwa Fitrah Allah:

Maksudnya ciptaan Allah. manusia diciptakan Allah mempunyai naluri beragama, yaitu agama tauhid. kalau ada manusia tidak beragama tauhid, Maka hal itu tidaklah wajar. mereka tidak beragama tauhid itu hanyalah lantaran pengaruh lingkungan. ${ }^{45}$

maka dalam ayat ini, fitrah adalah ketetapan Allah berupa hukum, karakter atau sifat dasar (naluri) yang ada pada manusia.

\section{Proses Penciptaan Alam}

Proses penciptaan alam, dalam Alquran sangat banyak disebutkan, hal tersebut agar manusia dapat mengerti akan hakekat penciptaan, termasuk diri dan lingkungannya yang sangat dekat, tidak lain bertujuan agar manusia beriman. Di antara ayat-ayat yang menunjuk tentang proses penciptaan adalah:

${ }^{44}$ Departemen Agama, Mushaf Al-Qur'an ..., h. 408.

${ }^{45}$ Ibid. 
- Q.S. al-Anbiyā' (21):30.

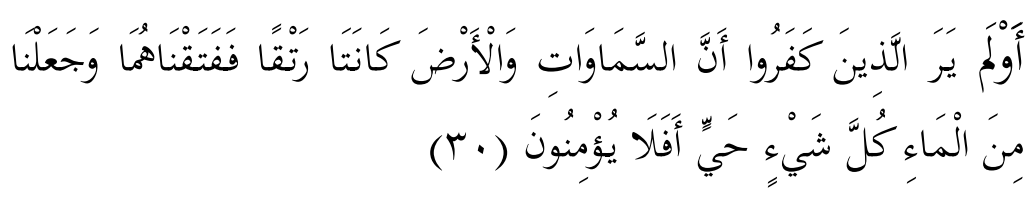

Dan Apakah orang-orang yang kafir tidak mengetahui bahwa langit dan bumi keduanya dahulu menyatu, kemudian Kami pisahkan antara keduanya; dan Kami jadikan segala sesuatu yang hidup berasal dari air. Maka mengapa mereka tidak beriman ${ }^{46}$

Ayat tersebut memberikan petunjuk keterpaduan alam raya kemudian pemisahannya dibenarkan oleh observasi para ilmuan. ${ }^{47}$ Yaitu dengan teori big ben seperti telah disebutkan sebelumnya, karena dalam ayat tersebut terdapat potongan

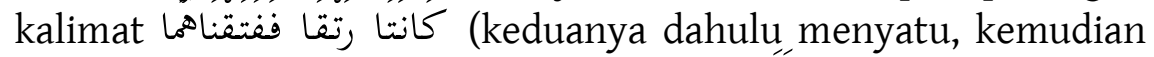

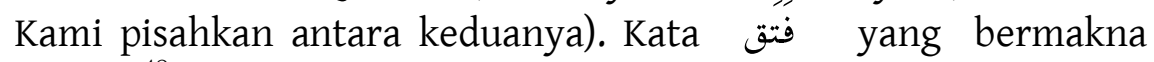
dasar فتح فن شيئ48 (membonkar sesuatu), kemudian al-Asfahāni memberikan makna bahwa memisahkan antara dua yang berhubungan, ${ }^{49}$ Hans Wher memberikan makna antara lain: celah, letusan, membanting, membelah, membengkak hingga pecah, lubuk air. ${ }^{50}$ Kesemua makna-makna tersebut, semakin menguatkan teori Big Beng.

Allah swt. dalam menginformasikan tentang terpisahnya antara langit dan bumi menggunakan kata فَتِنَ dengan memakai damīr nā yang menunjukkan kebesaran-Nya, tetapi bisa juga bermakna ada kesertaan yang lain dalam proses pemisahan, inilah yang menjadi temuan para ilmuan dengan teori big ben.

${ }^{46}$ Departemen Agama, Mushaf Al-Qur'an ..., h. 325.

${ }^{47}$ M. Quraish Shihab, Mukjizat Al-Qur'an, (edisi baru) (Cet. ke1; Bandung: Mizan, 2007), h. 177

${ }^{48}$ Ahmmad ibn Fāris ibn Zakarīya, Mu’jam Maqāyīs ..., h. 805.

${ }^{49}$ Al-Asfahānī, Al-Mufradāt ..., h. 373.

${ }^{50}$ Hans Wehr, A. Dictionary of Modern Written Arabic (Cet. ke-3; Beirut: Maktabah Lubnan,1980), h. 694-695. 
Memperhatikan makna penciptaan dalam Alquran seperti yang telah dijelakan, dan salah satu lafal yang digunakan adalah: "فاطر" kepada penciptaan langit dan bumi, dan di dalam Alquran disebutkan sebanyak enam kali, pada umumnya mufasir memaknai kalimat ini dengan menciptakan langit dan bumi, namun bila dilihat makna dasar dari kata ini, ---seperti telah disebutkan--- membuka sesuatu dan menampakkanya, lafal ini juga bermakna merobek, membelah, ${ }^{51}$ maka pemaknaan فاطر" "فاطر السماوات والأرض lebih tepat bila disesuaikan dengan pemaknaan bahasa, maka Q.S. al-Anbiyā' (21) 30 sebagai penafsiran dari فاطروات الأرض "السماوات والأرض.

- Q.S. Al-Zāriyāt (51):47.

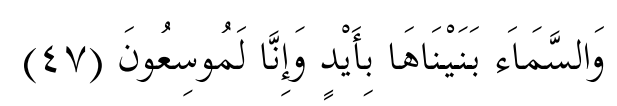

Dan langit Kami bangun dengan kekuasaan (Kami) dan Kami benarbenar meluaskannya. ${ }^{52}$

Kalimat وَإِنَّا لَمُوسعُون yang ada ayat ini sebagai isyarat, bahwa proses penciptaan langit/galaksi yang dikemukakan berlansung secara terus menerus, ${ }^{53}$ hal ini sejalan dengan teori "The Expanding Universe", menurut teori ini, alam semua bersifat seperti balon atau gelembung karet yang sedang ditiup ke segala arah. Langit yang kita lihat dewasa ini, sebenarnya semakin tinggi dan semakin mengembang ke segala arah dengan kecepatan yang luar biasa. ${ }^{54}$

M. Quraish Shihab mejelaskannya dengan mengacu kepada Q.S. Al-Gāsyiyah (88):17-18 berikut ini:

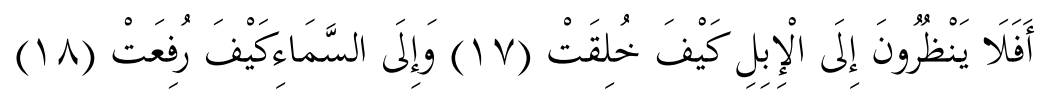

\footnotetext{
${ }^{51} \mathrm{Al}$-Imām al-'Allāmah Abū al-Faḍl Jamāl al-Dīn Muhammad ibn Makram ibn Manzūur, Lisān al-'Arab, juz 5 (Cet. ke1; Beirut: Dār Șādir, 1997), h. 140.

${ }^{52}$ Departemen Agama, Mushaf Al-Qur'an ..., h.523.

${ }^{53}$ Sāyf Munīr Fāris, al-I'jāza al-'Ilmī fĩ al-Qur'ān wa al-Sunnah (Cet. ke-1; Beirut: Dār Ibn Hazm, 2006), h. 163.

${ }^{54}$ M. Quraish Shihab, Mukjizat ..., h. 177.
} 
bahwa bumi kita diliputi oleh ruang angkasa atau langit, langit ditinggikan bearti ia bergerak sedemikian rupa ke arah tegak lurus pada seluruh permuaan bumi. Dan karena bumi bulat, berarti langit yang melindungi bumi itu harus mengembang ke segala arah. ${ }^{55}$ Hal tersebut sejalan dengan sifat hukum singularitas alam semesta, yang telah diteliti oleh para ilmuan ahir abad ke-20 di Universitas New York. ${ }^{56}$

- Q.S. Hūd (11):7.

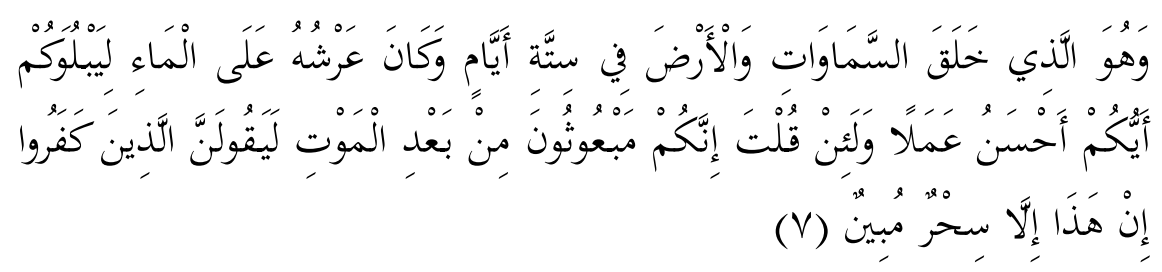

Dan Dia-lah yang menciptakan langit dan bumi dalam enam masa, dan 'Arasy-Nya di atas air, agar Dia menguji siapakah di antara kamu yang lebih baik amalnya, jika kamu berkata (kepada penduduk Mekah): "Sesungguhnya kamu akan dibangkitkan setelah mati", niscaya orangorang yang kafir itu akan berkata: "Ini hanyalah sihir yang nyata.

Dalam ayat ini, Allah menyebutkan bahwa penciptaan langit dan bumi dalam enam masa, yang dimaksud adalah enam tahap. Ulama tafsir sepakat bahwa enam tahap penciptaan dibagi menjadi tiga bagian, masing-masing bagian dua tahap. Tiga bagian tersebut adalah:

1) Dua hari untuk penciptaan bumi ketika dipisahkan dari langit,

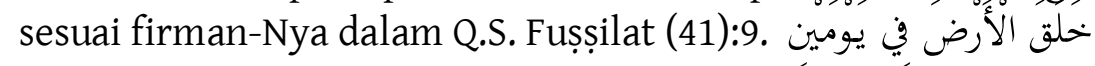

2) Dua hari untuk menyelaraskan langit yang tújư

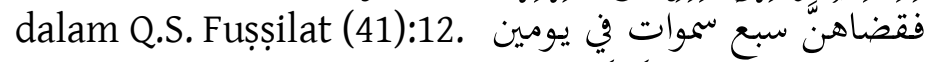

3) Dua hari untuk mengatur búmí secara geologi untuk kemaslahatan manusia. ${ }^{57}$

\footnotetext{
${ }^{55}$ Ibid.

${ }^{56}$ Andi Rosadisastra, Metode Tafsir..., h. 208.

${ }^{57}$ Sāyf Munīr Fāris, al-I'jāz al-'Ilmī ..., h. 189.
} 
Selain kedua ayat yang disebutkan, masih banyak lagi ayatayat lain yang hampir semakna. Sungguh Mahakuasa dan Mahasuci Dia, Pemilik kerajaan langit dan bumi:

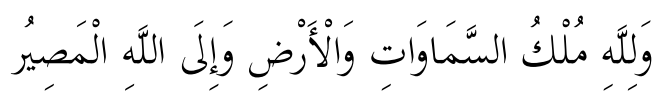

Dan kepunyaan Allah-lah kerajaan langit danhendaki bumi dan kepada Allah-lah kembali (semua makhluk).

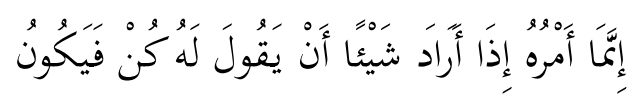

Sesungguhnya keadaan-Nya apabila Dia menghendaki sesuatu hanyalah berkata kepadanya: "Jadilah!" Maka terjadilah ia.

\section{Urgensi Penciptaan Alam}

\section{Agar Manusia Beriman}

Berbagai cara Allah swt. memperkenalkan eksistensi-Nya kepada makhluk-Nya, agar mereka percaya, beriman dan mengikuti sunnah-sunnah yang telah ditetapkan-Nya. Dan cara yang sangat logis dan dapat diterima oleh semua manusia yang berakal dengan memperhatikan proses dan fenomena semua apa yang terjadi di alam semesta ini.

Alquran banyak menggambarkan tentang fenomenafenomena alam, hal tersebut tidak lain kecuali untuk memperlihatkan kepada manusia siapa yang menciptakan dan mengatur semua itu, dan apa tujuannya? Dalam visi Alquran, fenomena alam tersebut merupakan tanda-tanda Yang Mahakuasa, dan suatu pemahaman tentang alam adalah analog dengan pemahaman tanda-tanda yang bisa membawa kita meraih pengetahuan Tuhan. $^{58}$ Oleh karena itu, dalam Alquran selalu mencantumkan bahwa fenomena alam dan proses penciptaannya merupakan tanda-tanda kekuasaan Allah yang harus

${ }^{58}$ Mahdi Ghulsyani, Filsafat Sains menurut Al-Qur'an, terj. Agus Efendi, edisi I (Cet. ke-9; Bandung: Penerbit Mizan, 1999), h. 78. 
diperhatikan, agar keimanan kepada-Nya semakin kuat dan kokoh. Antara lain ayat-ayat tersebut sebagai berikut:

- Q.S. al-Rūm (30):22.

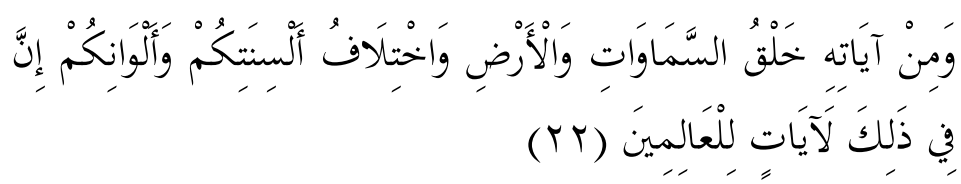

Dan di antara tanda-tanda kekuasaan-Nya ialah menciptakan langit dan bumi dan berlain-lainan bahasamu dan warna kulitmu. Sesungguhnya pada yang demikan itu benar-benar terdapat tanda-tanda bagi orangorang yang mengetahui. (22)

- Q.S. al-Rūm (30):24

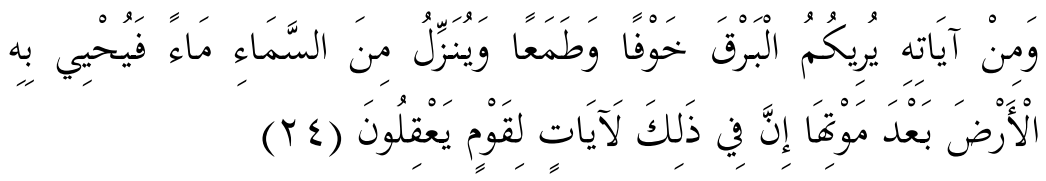

Dan di antara tanda-tanda kekuasaan-Nya, Dia memperlihatkan kepadamu kilat untuk (menimbulkan) ketakutan dan harapan, dan Dia menurunkan hujan dari langit, lalu menghidupkan bumi dengan air itu sesudah matinya. Sesungguhnya pada yang demikian itu benar-benar terdapat tanda-tanda bagi kaum yang mempergunakan akalnya.

- Q.S. Yūnus (10):101

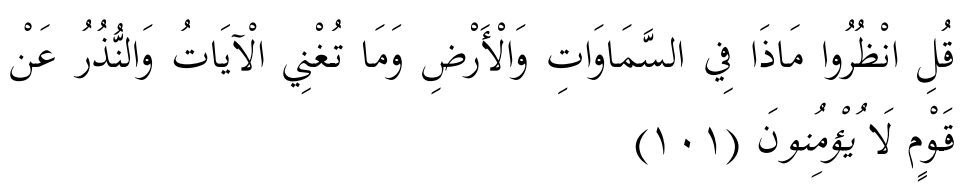

Katakanlah: "Perhatikanlah apa yaag ada di langit dan di bumi. tidaklah bermanfaat tanda kekuasaan Allah dan Rasul-rasul yang memberi peringatan bagi orang-orang yang tidak beriman".(101)

- Q.S. al-Żariyāt (51):20-21.

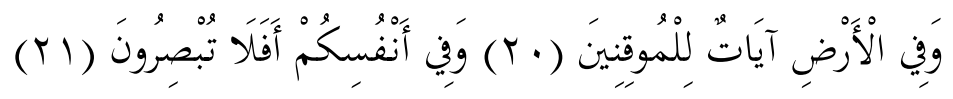

Dan di bumi itu terdapat tanda-tanda (kekuasaan Allah) bagi orangorang yang yakin.(20) Dan (juga) pada dirimu sendiri. Maka Apakah kamu tidak memperhatikan?(21) 
- Q.S. Fușșilat/41:53.

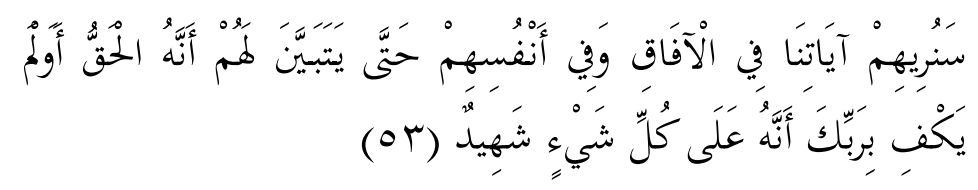

Kami akan memperlihatkan kepada mereka tanda-tanda (kekuasaan) Kami di segala wilayah bumi dan pada diri mereka sendiri, hingga jelas bagi mereka bahwa Alquran itu adalah benar. Tiadakah cukup bahwa Sesungguhnya Tuhanmu menjadi saksi atas segala sesuatu?

- Q.S. al-Naml (27):93

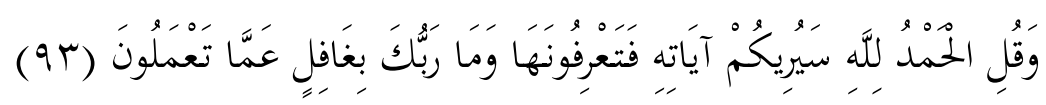

Dan Katakanlah: "Segala puji bagi Allah, Dia akan memperlihatkan kepadamu tanda-tanda kebesaran-Nya, Maka kamu akan mengetahuinya. dan Tuhanmu tiada lalai dari apa yang kamu kerjakan.(93)

\section{Untuk Kemaslahatan Umat Manusia}

Selain untuk keimanan kepada Allah swt. Alam juga diciptakan untuk kemaslahatan umat manusia, yaitu dengan memanfaatkan kekayaan yang dikandungnya, di samping sebagai tempat pijakan mereka melaksanakan fungsi dan aktifitasnya sehari-hari baik sebagai khalifah atau sebagai makhluk yang sama dengan makhluk lainnya.

Banyak sekali ayat yang menyebutkan bahwa alam dan kekayaan yang dkandungnya diciptakan untuk manusia. Di antara ayat-ayat itu adalah:

- Q.S. al-Jāsiyah (45):13.

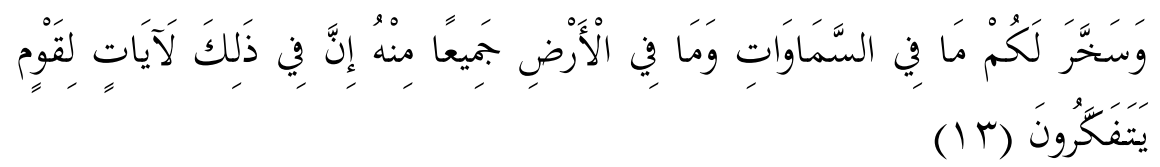

Dan Dia telah menundukkan untukmu apa yang di langit dan apa yang di bumi semuanya, (sebagai rahmat) daripada-Nya. Sesungguhnya pada 
Vol. 9, No. 1, Juni 2012: 55-84

yang demikian itu benar-benar terdapat tanda-tanda (kekuasaan Allah) bagi kaum yang berfikir (13)

- Q.S. al-A'rāf (7):10.

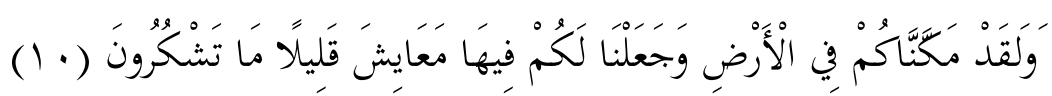

Sesungguhnya Kami telah menempatkan kamu sekalian di muka bumi dan Kami adakan bagimu di muka bumi (sumber) penghidupan. Amat sedikitlah kamu bersyukur.(10)

- Q.S. al-Qașaș (28):73.

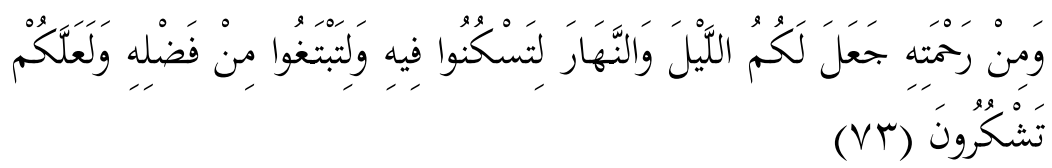

Dan karena rahmat-Nya, Dia jadikan untukmu malam dan siang, supaya kamu beristirahat pada malam itu dan supaya kamu mencari sebahagian dari karunia-Nya (pada siang hari) dan agar kamu bersyukur kepadaNya (73)

- Q.S. al-Rūm (30):46.

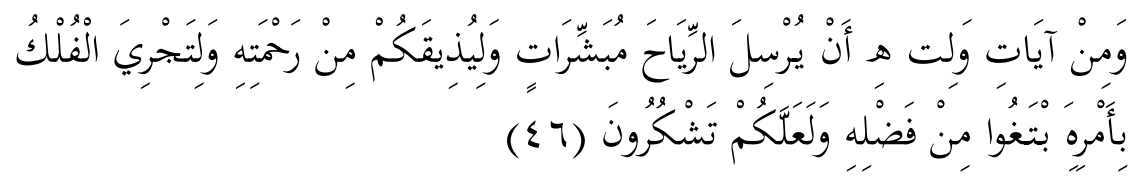

Dan di antara tanda-tanda kekuasan-Nya adalah bahwa Dia mengirimkan angin sebagai pembawa berita gembira dan untuk merasakan kepadamu sebagian dari rahmat-Nya dan supaya kapal dapat berlayar dengan perintah-Nya dan (juga) supaya kamu dapat mencari karunia-Nya; mudah-mudahn kamu bersyukur (46)

- Q.S. al-An‘ām (6):97.

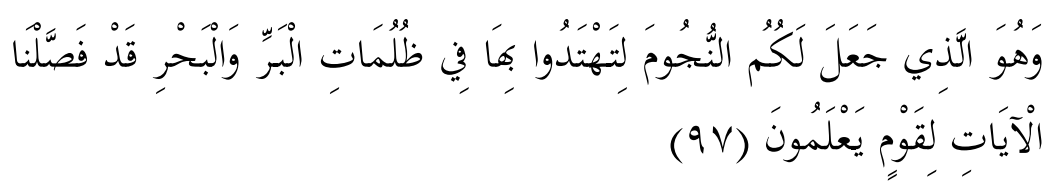

Dan Dialah yang menjadikan bintang-bintang bagimu, agar kamu menjadikannya petunjuk dalam kegelapan di darat dan di laut. 
Sesungguhnya Kami telah menjelaskan tanda-tanda kebesaran (Kami) kepada orang-orang yang mengetahui. (97)

Dari ayat-ayat yang disebutkan, alasan pengingat manusia akan rahmat-rahmat Allah adalah untuk menjadikannya akrab dengan pemberian-pemberian itu, untuk mendorongnya memanfaatkan pemberian itu sebagai pertanda kesyukurannya kepada Allah sebagai pemberi semua itu.

\section{Akhir Alam}

Para filosof tidak terlalu banyak berbicara tentang akhir dari alam ini. memeperhatikan pendapat para filosof bahwa alam ini qadìm dan azālī, kemungkinan besar juga mereka berpendapat bahwa alam ini akan kekal, karena dia. Tentu yang dimaksud alam nyata, tetapi adalah awal dari alam karena ia tercipta tidak dari seuatu, tanpa waktu dan ruang. Namun para teolog berpendapat, bahwa segala sesuatu selain Allah bisa menerima ketiadaan dan kemusnahan, karena alam berasal dari yang tidak ada, maka dia baharu, sesmua yang baharu, pada hakekatnya bisa menerima tidak ada dan ada. ${ }^{59}$ Tentu yang mereka maksudkan adalah alam yang ada sekarang yang tercipta melalui proses. Setiap sesuatu yang berawal, pasti mempunyai akhir, ini merupakan hukum alam atau sunnatullah yang pasti berlaku. Salah satu dalil yạng menjadi dasar para teolog adalah Q.S. al-Qalam (28):88 .... كل ....

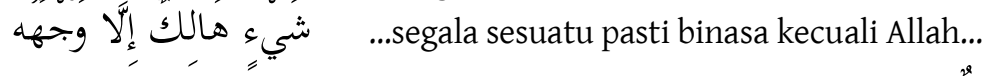

Para mufassir berbeda interpretasi tentang arti هَالكُ, ada yang menafsirkan dengan tidak ada, dengan demikian ayat bermakna bahwa Allah meniadakan segala sesuatu selain dirinya, ada juga yang menafsirkan dengan tidak dapat berfungsi lagi apakah dengan cara mematikan atau memisahkan bagianbagianya. ${ }^{60}$

\footnotetext{
${ }^{59}$ Al-Rāzì, Tafsīr al-Fakhr ..., juz 5, h. 23

${ }^{60}$ Ibid.
} 
Al-Asfahānī menyebut makna "الهالكا" dalam ada empat, yaitu: 1). hilangnya sesuatu dari seseorang tetapi pada orang lain tetap ada, 2). rusak, 3). mati , dan 4). musnah. ${ }^{61}$ Dengan demikian, pemaknaan dengan lenyap (tidak ada) segala sesuatu termasuk alam berdasarkan ayat ini merupakan interpretasi dari mufassir. Karena diantara makna-makna yang disebutkan bisa saja semua benar bila sandarkan kepada alam. Karena lafal شيs adalah umum karena berbentuk nakirah dan dikutakan lagi"dengan lafal $\int^{2}$.

Selain ayat tersebut, ada beberapa ayat lebih spesifik mengisyaratkan akan berahirnya alam ini (al-kaun) yang merupakan penekanan pembahasan. Antara lain sebegai berikut:

- Q.S. al-Anbiyā' (21): 104.

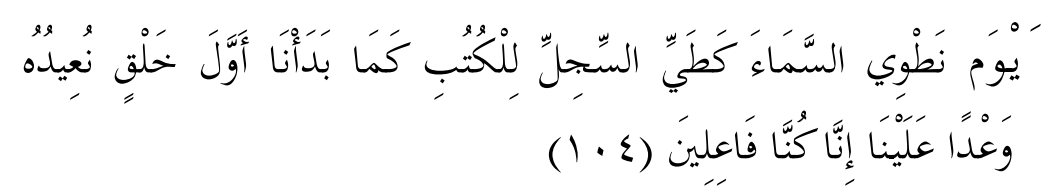

(Ingatlah) pada hari langit Kami gulung seperti menggulung lembaran lembaran kertas. sebagaimana Kami telah memulai panciptaan pertama Begitulah Kami akan mengulanginya. (Suatu) janji yang pasti Kami tepati; Sungguh kami Kami akan melaksanakannya. ${ }^{62}$

Kata نَطْوي dalam ayat tersebut berasal dari kata طوى yang berarti "melipat". Pengguanaan lafal ini dengan kata kerja dan damīr nahnu, mengisyaratkankan bahwa pelipatan langit melalui proses yang Allah ątur, sesuai, keinginan-Nya. Kemudian ada potongan ayat: كَمَا بَدَأْنَا أَوَََّ خَلْق نعيده mengisyaratkan, bahwa makna نَطوي tidak śekedar melipat, tetapi eksistensi dari alsamā' bisa saja ditiadakan kemudian diadakan kembali dengan

${ }^{61}$ Al-Asfahānī, al-Mufradāt ..., h. 522.

${ }^{62}$ Departemen Agama, Mushaf Al-Qur'an ..., h. 332. 
proses sebagaimana penciptaan pertama. ${ }^{63}$ Peristiwa pemusnahan alam ini, dalam teori ilmiah disebut dengan "Big Crunsh" ${ }^{34}$

- Q.S. Ibrāhīm (14): 48.

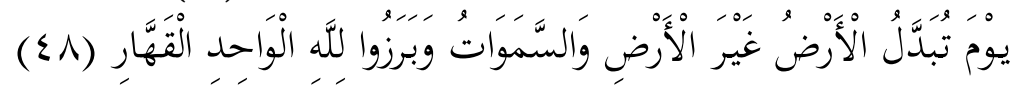

(yaitu) pada hari (ketika) bumi diganti dengan bumi yang lain dan (demikian pula) langit, dan meraka (manusia) berkumpul (di padang Mahsyar) menghadap Allah yang Maha Esa lagi Maha Perkasa. ${ }^{65}$

Ayat tersebut menggambarkan, bahwa langit dan bumi yang sekarang, akan hilang dan digantikan dengan langit dan bumi lainnya pada saat datangnya yang dikatakan hari kiamat. Kata

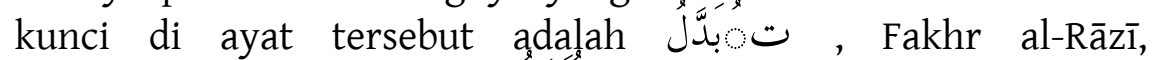
menyebutkan bahwa makna تبدَّلَ mempunyai dua kemungkinan, yang pertama, bahwa zatnya tetap ada, tetapi yang terganti adalah sifat, dan kedua adalah zat yang terganti dan digantikan dengan zat yang lain, dan تبََّّلْ memungkinkan kedua hal ini terjadi. $^{66}$

Dengan kedua ayat yang disebutkan, dapat disimpulkan bahwa bila terjadi hari kiamat nanti, maka manusia akan berada di alam lain selain alam yang ada sekarang, di mana alam tersebut, bisa saja sama zat atau sifatnya dengan alam yang sekarang atau berbeda (zat atau sifatnya).

\section{PENUTUP}

Di dalam akidah Islam, alam adalah semua yang ada selain Allah. Tidak menutup kemungkinan, masih banyak alam yang belum terungkap oleh pengetahuan manusia, dan yang kita

\footnotetext{
${ }^{63}$ Al-Allāmah Jārullāh Abū al-Qāsim Maḥmūd ibn Umar al-Zamakhsyarī, al-Kasysyāf 'an Haqā'iq Gawāmiḍ al-Tanzīl wa 'Uyūn al-Aqāwīl fī Wujūh al-Ta'wīl, taḥqīq 'Ādil Ahmad 'Abd al-Maujūd dan 'Alī Muhammad Ma'awwaḍ, juz 4(Cet. I; al-Riyāḍ: Maktabat al-‘Abīkān, 1998), h. 168.

${ }^{64} Y$ ūsuf al-Hāj Umar, Mausū'at al-I'jāz al-'Ilmī fī al-Qur'ān wa al-Sunnah al-Muțahharah (Cet. II; Dimisyqa: Maktabah Dār Ibn Hajr, 2003), h. 315.

${ }^{65}$ Departemen Agama, Mushaf Al-Qur'an ..., h. 262.

${ }^{66}$ Al-Rāzī, Tafsīr al-Fakhr ..., juz 25, h. 23.
} 
ketahui dengan indra atau hasil temuan pengetahuan adalah bagian dari alam yang diperintahkan untuk tetap diteliti. Oleh karena itu, banyak ayat Alquran yang merangsang akal pikiran manusia untuk memerhatikan penciptaan-Nya, apakah penciptaan itu melalui proses atau tidak melalui proses sesuai dengan kehendak Penciptanya.

Alam adalah ciptaan Allah. Dialah yang mengatur dan memeliharanya melalui aturan-aturan dan hukum-hukum yang telah ditetapkan-Nya yang disebut dengan "hukum alam", kesemuanya mempunyai tujuan yaitu agar manusia beriman kepada penciptanya, dan sebagai tempat untuk melaksanakan fungsinya sebagai khalifah; dan akhirnya semua yang diadakan, suatu saat pasti ditiadakan, dan akan diadakan kembali, itulah hakikat alam.

\section{DAFTAR PUSTAKA}

Allūsī, Abū al-Faḍl Syihāb al-Dīn al-Sayyid Mahmūì al-. Rūḥ al-Ma‘ānī fĩ Tafsìr al-Qur'ān al-'Azīm wa al-Sab' al-Maṡānī. Beirut: Dār Ihyā̄' alTurās al-'Arabī, t.th.

Aṣfahānī, Abū al-Qāsim al-Ḥusain ibn Muhammad al-Rāghib al-. AlMufradāt fī Gharīb al-Qur'ān, cet. ke-5; Beirut: Dār al-Ma'rifah, 2007.

Baișār, Muhammad al-. Fī Falsafat ibn al-Rusyd, al-Wujūd wa al-Khulūd, Cet. ke-3: Beirut: Dār al-Kitāb al-Lubnānī, 1973.

Bāqī, Muhammmad Fu'ad 'Abd al-. Al-Mu'jam al-Mufahras li al-Fāz alQur'ān al-Karīm, cet. ke-3; Cairo: Dār al-Hadīśs, 1991.

Departmen Agama, Mushaf Al-Qur'an Terjemah, edisi 2002. Jakarta: Pena Pundi Aksara, 2006.

Fāris, Nāyf Munīr, al-I'jāz al-'Ilmī fĩ al-Qur'ān wa al-Sunnah, cet. ke-1; Beirut: Dār ibn Hazm, 2006.

Ghulsyani, Mahdi, Filsafat Sains menurut Al-Qur'an, terj. Agus Efendi, edisi I, cet. ke-9; Bandung: Penerbit Mizan, 1999. 
Hāsyimī, al-Sayyid Ahmad al-. Jawāhir al-Balāghah fī al-Ma‘ānī wa alBayān wa al-Bad̄̄', cet. ke-1; Beirut: Maktabat al-'Așrīyah, 1999.

Huwaidī, Yahya. Dirāsāh fī 'Ilm al-Kalām wa al-Falsafah al-Islāmīyah. Cairo: Dār al-Śaqāfah, t.th.

Ibn Manẓūr, al-Imām al-'Allāmah Abū al-Faḍl Jamāl al-Dīn Muhammad ibn Makram. Lisān al-'Arab, juz 5, cet. ke-1; Beirūt: Dār Șādir, 1997.

Imām, Zakarīya Bașīr. Tārīkh al-Falsafat al-Islāmīyah, Dirāsat Madkhāliyah Muyassarah, cet. ke-1; Khurtūm: Dār al-Sūdānīyah li al-Kutub, 1998.

Jurjānī, al-'Allāmah 'Alī ibn Muḥammad al-Syarīf al-. Kitāâb al-Ta'rīfāh. Beirut: Maktabah Lubnān, 1985.

Miṣrī, ibn Abū al-Ișba‘ al-. Bad̄̄` al-Qur’ān, Taḥqīq Ḥifnī Muhammad Syarîf . Cairo: Nahḍat al-Mișr, t.th.

Murata, Sachiko. The Tao of Islam, terj. Rahmani Astuti dan M.S. Nasrullah, cet. ke-9; Bandung, PT. Mizan Pustaka, 2004.

Rāzī, al-Imām Muhammad Fakhr al-Dīn ibn al-'Allāmah Ḍiyā' al-Dīn al-. Tafsīr al-Fakhr al-Rāzī al-Musytahīr bi Tafsīr al-Kabīr auw Mafätīh al-Ghaib , juz 4, cet. ke-1; Beirut: Dār al-Fikr, 1981.

Rosadisastra, Andi. Metode Tafsir Ayat-ayat Sains dan Sosial, cet. ke-1; Jakarta: Amzah, 2007.

Salībā, Jamīl. Al-Mu'jam al-Falsafî, juz 2. Beirut : Dār al-Kitāb al-Lubnān̄̄, 1982.

Shihab, M. Quraish. Mukjizat Al-Qur'an, edisi baru, cet. ke-1; Bandung: Mizan, 2007.

Ṭabarī, Abū Ja‘far Muhammad ibn Jarīr al-. Tafsīr al-Ṭabarī, Jāmi alBayān 'an Ta'wīl Âyat al-Qur'ān, taḥīq Abdullāh ibn 'Abd alMuhsin al-Turkī, juz 9, cet. ke-1; Cairo: Dār al-Hajr, 2001.

Tim Redaksi Kamus Bahasa Indonesia, Kamus Bahasa Indonesia. Jakarta: Pusat Bahasa Departemen Pendidikan Nasional, 2008.

Umar,Yusuf al-Hāj. Mausū'at al-I'jāz al-'Ilmī fĩ al-Qur'ān wa al-Sunnah al-Muțahharah, cet. ke-2; Dimisyqa: Maktabah Dār ibn Hajr, 2003.

Wehr, Hans. A. Dictionary of Modern Written Arabic, cet. ke-3; Beirut: Maktabah Lubnān,1980. 
Vol. 9, No. 1, Juni 2012: 55-84

Zakarīya, Abū al-Ḥusain Aḥmad ibn Fāris ibn. Mu'jam Maqāyīs alLughah, cet. ke-1; Beirut: Dār Ihyāa al-Turās al-'Arabī, 2001.

Zamakhsyarī, al-Allāmah Jarullāh Abū al-Qāsim Maḥmūd ibn Umar al-. Al-Kasysyāf 'an Haqā̄iq Gawāmị̣ al-Tanzīl wa 'Uyūn alAqāwīl fī Wujūh al-Ta'Wīl, tahqīq 'Adil Aḥmad 'Abd al-Maujūd dan Alī Muhammad Ma'awwad, juz 4, cet. ke-1; al-Riyāḍ: Maktabat al-‘Abīkān, 1998.

Zar, Sirajuddin. Filsafat Islam, Filosof dan Filsafatnya, cet. ke-4; Jakarta: PT. Raja Grafindo Persada, 2010. 